\title{
INFÂNCIA E EDUCAÇÃO: A HISTÓRICA CONSTRUÇÃO DO DIREITO DAS CRIANÇAS
}

\author{
Djanira Ribeiro Santana \\ Universidade Estadual do Sudoeste da Bahia - UESB
}

\section{RESUMO}

O presente artigo tem por finalidade realizar uma breve abordagem histórica sobre a maneira como a infância tem sido vista e tratada pela sociedade ocidental em diferentes épocas, desde a Antiguidade, passando pela Idade Média e Moderna até a Contemporaneidade. Busca-se compreender como a partir do advento e consolidação da Modernidade, foi desenvolvida uma nova concepção de infância alicerçada nos ideais da sociedade burguesa. Para isso, foram realizados estudos sobre Rousseau, Pestalozzi e Froebel, os precursores da Educação Infantil na Europa, que inauguraram uma nova concepção de criança como um ser naturalmente bom. $\mathrm{O}$ texto também apresenta uma abreviada análise histórica acerca da situação da infância brasileira e da educação a ela direcionada, desde o período Colonial até a atualidade, relatando os percursos da infância na luta pela conquista do Direito das crianças de zero a cinco/seis anos a ter uma Educação Infantil pública de qualidade.

Palavras-chave: Concepções de Infância. Educação Infantil. Infância Brasileira. Filantropia e Assistência.

\section{CHILDHOOD AND EDUCATION: THE HISTORICAL CONSTRUCTION OF THE RIGHT OF CHILDREN}

\begin{abstract}
This article aims to make a brief historical perspective on how childhood has been seen and treated by western society at different times, since antiquity through the Middle Ages to the Contemporary and Modern. We seek to understand how the advent and consolidation of modernity, we developed a new conception of childhood grounded in the ideals of bourgeois society. For this, studies were performed on Rousseau, Pestalozzi and Froebel, the precursors of early childhood education in Europe, which opened a new conception of the child as a being naturally good. The text also presents a short historical analysis of the situation of Brazilian children and education directed to it, from the Colonial period to the present, recounting the journeys of childhood in the struggle for the right of children zero to five / six years have a quality public kindergarten.

Keywords: Conceptions of Childhood. Early Childhood Education. Childhood Brazilian. Philanthropy and Service.
\end{abstract}

\section{Introdução}

Atualmente a situação da infância no mundo vem sendo palco de debates em diferentes setores da sociedade, tais como: na política, no meio jurídico, nas escolas, nas universidades, na mídia, nas associações comunitárias e entidades não governamentais. Todos demonstram preocupação com as condições em que se encontram milhares de crianças em todo mundo, vítimas de toda espécie de violência sejam elas físicas, psicológicas ou sociais. Esta infância tornou-se vítima indefesa da globalização excludente, da pobreza, das guerras, do abandono familiar, da pedofilia, das drogas, da falta de escolas, da violência urbana, dentre outros problemas. 
Todavia, nem sempre foi assim, essa preocupação com a infância surgiu a partir da Modernidade, quando nasceu uma nova concepção de infância e com ela a criança passou a usufruir de maior proteção dos adultos; inicialmente na família e posteriormente de instituições sociais, sendo a principal delas a escola.

Este texto almeja apresentar uma síntese da trajetória da infância no mundo ocidental, abordando suas diferentes concepções construídas ao longo do tempo, enfatizando a maneira como a criança pequena tem sido tratada por diversas sociedades na Europa e no Brasil.

Inicialmente abordar-se-á sobre a violência e exclusão social que tem caracterizado a história da infância no mundo inteiro desde a Antiguidade, passando pela Idade Média, Modernidade, alcançando a Contemporaneidade. Neste contexto, será discutido como a concepção de infância foi sendo construída ao longo do tempo de acordo com o contexto histórico e sociocultural de cada sociedade. Em seguida o texto relata de maneira resumida o pensamento filosófico de Rousseau, Pestalozzi e Froebel, os precursores da Educação Infantil. Eles inauguraram uma nova concepção de Infância na Europa ao apresentar a criança como um ser naturalmente bom.

Posteriormente, será abordado um pouco do percurso da infância brasileira na luta pela conquista do direito à Educação Infantil desde a criação das primeiras instituições no Brasil imperial, até a educação infantil tornar-se um direito das crianças de zero a seis anos com a promulgação da Constituição de 1988 e a efetivação desses direitos através da promulgação LDB 9394/96. Dessa maneira pretende-se provocar a reflexão e incentivar o debate acerca dos desafios enfrentados por esta etapa educacional na luta pela consolidação do direito das crianças de zero a cinco/seis anos à Educação Infantil.

\section{Infância: uma categoria historicamente permeada pela violência e a exclusão social}

No decorrer de sua História, a infância tem sido vista sob diferentes prismas, sua concepção tem se modificado de acordo com o contexto histórico em que está inserida. Neste sentido, o fato de as crianças sempre ter existido na História da humanidade, não significa que elas sempre foram notadas e tratadas da mesma forma, mesmo porque a concepção de infância nasceu com o advento da Idade Moderna. Segundo Ariès (1981), na Idade Média, não existia o sentimento infância como há hoje. As crianças eram consideradas uma espécie de adulto em miniatura, elas eram tratadas apenas como seres biológicos, descendentes do ser humano e dependentes dos adultos até adquirir independência física, depois disso misturavam-se a eles no trabalho.

Sentimento de infância para Ariès (1981) não significa afeição pelas crianças, mas um sentimento de particularidade para com a criança em relação ao adulto. É uma maneira diferenciada de se olhar para a infância, percebendo as diferenças entre esta e o adulto. Conforme o autor, esse sentimento iniciou-se com a paparicação da criança e evoluiu com a ascensão da burguesia que começou a ver a necessidade de moralizá-la através da educação preparando-a para assumir futuramente o papel social imputado pela família e a sociedade burguesa.

Ainda de acordo com as pesquisas realizadas por Ariès (1981), as crianças eram excluídas da vida social. Quando apareciam, eram como herdeiras ou nas pinturas que representavam o menino-Deus, nas quais Jesus era retratado com características tipicamente adultocêntricas (corpo frágil e face de homem). Este fato comprova sua teoria, segundo a qual a criança era representada na Idade Média como um adulto em miniatura. 
Segundo Sarmento (2007), a palavra infância é de origem latina, cujo sentido etimológico significa "aquele que não fala" (in) - negação, (fans) - o que não fala. Sendo assim, em algumas sociedades antigas as crianças muito pouco ou nada valiam, elas eram vítimas de castigos físicos e práticas como o infanticídio e o filicídio, sem que seus agressores (que na maioria das vezes eram os próprios pais) fossem punidos. Não havia leis que as protegessem contra as diferentes formas de violência e exclusão social praticada pelos adultos.

Entre povos antigos como os hebreus, os gregos e os romanos a prática do infanticídio era aceita com naturalidade e a criança não gozava de nenhum prestígio ou direito. Não havia espaço para os deficientes, as crianças que nasciam com alguma deficiência ou aparentemente fracas eram discriminadas, ou até mesmo eliminadas, prática considerada normal para aquelas sociedades. Em Roma, os pais possuíam direito sobre a vida dos filhos, a prática do abandono e do sacrifício de crianças recém-nascidas fisicamente deficientes era instituída pelo Direito romano. Percebe-se aí, que a violência e a exclusão social da infância é uma prática antiga entre os ancestrais da humanidade.

Na Grécia Antiga, em especial em Atenas e Esparta, as crianças não eram vistas como categoria especial, atitudes como o infanticídio eram comum numa sociedade guerreira que supervalorizava a força física e a coragem. Sendo assim, não havia espaço nesta sociedade para as crianças que nascessem vítimas de qualquer deficiência física. Postman (1999) salienta que apesar da dedicação dos gregos para com a criação de escolas e da preocupação de filósofos como Platão em ensinar aos jovens a virtude e coragem, os gregos não hesitavam em castigá-los fisicamente, pois não havia entre eles a concepção de infância tal como conhecemos hoje.

Segundo Kohan (2006), a criança para Platão não tinha nenhuma significância, mas sim o que nela poderia ser incutido. Era importante educar na infância porque a criança de hoje seria para ele o futuro governante da polis e precisaria saber governá-la dentro da normalidade. $\mathrm{Na}$ intenção de formar o futuro governante da polis, a criança devia ser moldada de acordo um paradigma pré-estabelecido de regras a cumprir ajustando-se ao que deve vir a ser.

No período da História do Ocidente denominado de Idade Média que teve início em 476, com a queda do Império Romano e terminou em 1453 com a tomada de Constantinopla pelos turcos, a criança continuou tendo pouquíssimo ou nenhum valor. Esse tempo foi marcado, segundo Aranha (1996), pelo sistema de produção feudal, no qual a vida e as atividades rurais se sobrepunham ao modo de vida urbana - processo chamado de ruralização. Neste novo modelo de sociedade, a Igreja Católica se impunha como a instituição social mais poderosa da época. Ela interferia nas relações sociais determinando o comportamento moral das pessoas em sociedade, influenciando as decisões políticas e jurídicas, controlando a educação num mundo onde apenas os monges dominavam a leitura e a escrita, enquanto os demais eram considerados iletrados.

$\mathrm{Na}$ sociedade medieval, os hábitos das pessoas eram bem diferentes dos nossos, conforme Postman (1999) era inexistente a prática de hábitos de higiene, o que contribuía para o alto índice de mortalidade infantil tornando breve a vida da maioria das crianças. Outro hábito bizarro daquela sociedade era a ausência de regras morais no trato para com as crianças, eles brincavam com os órgãos genitais dos pequenos e empregavam uma linguagem vulgar em sua presença desconsiderando a inocência infantil. O autor salienta ainda que naquela época, a infância terminava aos sete anos, idade em que a criança dominava a língua oral, e era estipulado pela Igreja como a "idade da razão" supõe-se que com sete anos os indivíduos já sabiam separar o bem do mal. 
Na visão teológica de Santo Agostinho a criança era imperfeita e má por natureza, pois ela herdava dos pais o pecado original e por isso era considerada um símbolo do mal. Neste sentido, a função primordial da educação era salvar a alma da criança e discipliná-la. Para ele, apenas uma criança era importante e deveria servir de modelo de infância, devido sua pureza, sinceridade e santidade, o menino Jesus.

Assim, o objetivo maior da educação para Santo Agostinho é a salvação da alma. Todas as áreas do conhecimento, isto é, as matérias, tais como: literatura, retórica, lógica, aritmética e os exercícios físicos, deveriam ser vistos como um meio, cuja finalidade seria o aprimoramento da cultura religiosa e, para alcançá-la, o educador deveria utilizar todos os recursos que lhe fossem disponíveis, até mesmos os castigos físicos, contanto que moldasse a natureza pecaminosa da criança (SOUZA, 2010, p. 20).

Percebe-se aí claramente a inexistência do sentimento de infância, pois a criança era vista e tratada com austeridade, sua liberdade e direito de brincar não eram respeitados, ela não era considerada como cidadã de Direito. Além disso, a educação possuía um caráter totalmente doutrinário, autoritário e moralista, muito distante da natureza infantil marcada pelo lúdico, pela espontaneidade e curiosidade natural da criança. Tais características próprias das crianças eram totalmente desconsideradas pela rígida visão de educação agostiniana.

Outro filósofo que também ver a criança como má é Thomas Hobbes, sua concepção filosófica de criança está fundamentada na ideia do pecado original. Em sua teoria o Estado exerce poder sobre os cidadãos e os pais sobre as crianças, cuja natureza precisa ser "domesticada", e controlada. De acordo com essa teoria "[...] a criança é concebida como uma expressão de forças indomadas, dionisíacas, com potencialidade para o mal" (SARMENTO, 2007, p. 31). Assim, a criança precisa ser domada pela razão humana, o que seria realizado por meio da educação. Para Sarmento (2007), na contemporaneidade este conceito de criança má incide sobre as crianças oriundas das camadas populares, sobre as quais recai a ação paternalista do Estado e suas medidas repressoras.

Sarmento (2002), afirma que os veículos de comunicação nos induzem a acreditar que a infância passa por uma crise social de valores. A mídia tem o poder de legitimar a imagem da infância junto à sociedade fazendo-a vê-la sob duas óticas opostas. De um lado, ela é vista como sinônimo de inocência e tranquilidade, de outro é marginalizada, fruto de uma sociedade em crise e transgressora de normas sociais, vista ora como vítima da violência, ora como promotora dela. $\mathrm{O}$ autor aponta vários fatores que contribuem para a exclusão social da infância como: a pobreza e o desemprego, a desestrutura familiar, a crise educacional, e a globalização, dentre outros. Segundo Sarmento:

[...] as condições da modernidade tardia e da globalização, ao contrário de trazerem consigo a erradicação da exploração do trabalho de menores, criaram as condições de sua generalização, quer nos países periféricos, quer nos países semiperiféricos e centrais, nos setores da indústria que fundam a sua competividade nos baixos custos da mão-de-obra assalariada [...] (SARMENTO, 2002, p. 271).

Neste contexto, são notáveis as consequências da globalização para a exclusão social da infância, uma vez que a desigualdade na distribuição de renda atinge, sobretudo, as populações mais carentes e menos protegidas por políticas sociais, estas são compostas 
pelas famílias mais pobres e jovens, o que significa afirmar que a pobreza e a desigualdade social atingem com mais intensidade a população infantil. Um estudo realizado em Portugal, por Rua (2007) revelou o quanto a condição socioeconômica determina o modo de se vivenciar a infância, promovendo uma segregação social desde as brincadeiras, passando pelas diferentes maneiras de lidar com fracasso ou o sucesso na escola, na escolha da profissão, enfim, há culturas distintas para infâncias socialmente diferenciadas.

No Brasil, Sônia Kramer é uma das autoras que denuncia a violência e a exclusão social pelas quais as crianças estão passando no mundo contemporâneo. A pesquisadora afirma que as crianças são marcadas pelas contradições da sociedade em que vivem, e o que se assiste é uma verdadeira situação de barbárie cometida contra nossas crianças e adolescentes.

Kramer (2008) denuncia as péssimas condições de vida provocada pela extrema pobreza em que vivem milhares de crianças brasileiras. Aponta ainda a ausência de políticas direcionadas à infância e a ineficácia da política educacional direcionada às creches e pré-escolas. Além disso, critica a ausência de formação, valorização profíssional e salarial dos professores que atuam na educação infantil, bem como, o descumprimento de leis que foram resultado de conquistas populares como a Constituição de 1988, o Estatuto da Criança e do Adolescente de 1990 e a LDB 9.394/96.

Dessa forma, apesar da sociedade contemporânea ter assistido a um rápido processo de evolução científico-tecnológica, político-econômica e cultural nas últimas décadas, as crianças ainda continuam sendo vítimas das mais diversas formas de violência e exclusão social. A comprovação desse fato encontra-se publicado nos diferentes meios de comunicação que através de suas reportagens denunciam: a exploração do trabalho infantil, a pedofilia, a exploração sexual infantil, crianças sendo vítimas de guerras, abandonadas, dependentes de drogas, vítimas de maus-tratos na família e da ausência ou ineficiência de políticas públicas que as protejam contra marginalização social, educacional e cultural.

\section{Rousseau, Pestalozzi e Froebel os precursores da Educação Infantil, inauguraram uma nova concepção de Infância na Europa.}

A partir dos séculos XV, XVI e XVII a Renascença, o advento e fortalecimento de uma nova classe social; a burguesia, e a consolidação da Modernidade provocaram grandes modificações na Europa. Este período foi marcado por uma verdadeira revolução do pensamento humano em contraposição aos valores medievais. De acordo com Kramer (2011) as descobertas científicas realizadas no século XVI com a chegada do Renascimento promoveram uma grande redução no índice de mortalidade infantil nas classes dominantes. Este acréscimo da perspectiva de vida foi um dos fatores que colaborou para o surgimento do sentimento de infância. Paralelo a ele ocorreram outras transformações sociais, culturais, políticas e econômicas advindas com o declínio da sociedade medieval e o aparecimento das ideias iluministas.

No século XVIII, Jean Jacques Rousseau (1712 - 1778), um importante filósofo iluminista, publicou em (1762) seu romance "Emílio ou Da Educação", no qual inaugurou uma nova concepção de infância ao reconhecer a criança como um ser naturalmente bom. Para ele em sua natureza original a criança era naturalmente boa, a sociedade é quem a corrompia. Neste sentido, a infância é uma fase de grande relevância na vida do ser humano, pois é nela que se dá o aprendizado de como ser no futuro um grande homem. Daí, a importância de respeitá-la, como uma fase natural na vida da criança, na qual ela pode ser verdadeiramente criança antes de tornar-se adulto. 
Amai a infância; favorecei seus jogos, seus prazeres, seu amável instinto. Quem de vós não se sentiu saudoso, às vezes, dessa idade em que o riso está sempre nos lábios e a alma sempre em paz? Por que arrancar desses pequenos inocentes o gozo de um tempo tão curto que lhes escapa, de um bem tão precioso de que não podem abusar? (ROUSSEAU, 1995, p. 61).

Para o autor, a criança possui suas peculiaridades e o adulto não deve impor-lhes suas maneiras de pensar, de ver e sentir, pois, segundo ele: "Se quisermos perturbar essa ordem, produziremos frutos precoces, que não terão maturação nem sabor e não tardarão em corromper-se; teremos jovens doutores e crianças velhas" (ROUSSEAU, 1995, p.75). Todavia, o próprio autor adverte para o fato de que o educador ao respeitar a liberdade da criança não deve confundi-la com a satisfação de todos os seus caprichos. Percebe-se então, o quanto é importante impor limites às crianças, pois ambos (liberdade e limite) precisam caminhar em parceria na educação da infância, sem que um se sobreponha ao outro, assim será desenvolvido na criança um conceito de fundamental importância em seu processo educativo, a noção de respeito a si própria e ao outro.

Rousseau (1995) vê a criança como um ser pensante, contudo distinto do adulto. Para ele a criança nasce desprovida de tudo e a educação é a grande responsável por darlhe tudo o que precisará na vida adulta. Nesta perspectiva, a educação possui uma ação transformadora na vida da criança, para isso é necessário que a mesma seja planejada visando proporcionar às crianças uma experiência do real e que o professor saiba motiválas, despertando-lhes a curiosidade e o desejo de aprender. Dessa forma, a criança crescerá livre para brincar e aprender construindo seu próprio conhecimento através do contato com a realidade mediatizado pelos adultos.

Assim como Rousseau, Froebel e Pestalozzi também veem a criança como um ser naturalmente bom, segundo esses autores, os adultos precisam aprender a respeitar as crianças, sua liberdade, inocência e direito de brincar. "Para Pestalozzi a criança é naturalmente boa, os castigos físicos em nada ajudam [...]", (ARCE, 2002, p. 119). Sendo assim, tanto Pestalozzi quanto Froebel contribuíram para a inauguração de uma nova concepção de infância na Europa. "Froebel já vê a criança como portadora natural de tudo o que existe de melhor no ser humano" (ARCE, 2002, p. 127). Ambos idealizaram uma visão romântica de infância, na qual era valorizada a função da religião protestante na educação das crianças e o papel da mãe como educadora inata, sustentáculo da educação na primeira infância.

Embora esses autores tenham pontos em comum em suas teorias sobre a concepção de infância e educação tais como: o respeito ao direito das crianças brincarem, o reconhecimento da mulher-mãe como educadora inata da primeira infância e considerem a criança como um ser naturalmente bom, há também divergências entre eles, mesmo que um tenha sido discípulo do outro.

Johann Heinrich Pestalozzi (1746 - 1827) educador suíço tinha uma concepção de educação em que, a criança é o centro do processo educacional. Partindo desse princípio, era necessário conhecer o desenvolvimento humano para criar métodos de ensino eficazes. Educar partindo do mais simples para o mais difícil, respeitando a liberdade da criança, valorizando seus conhecimentos prévios e usando objetos concretos que facilitem sua compreensão. De acordo com Arce (2002), a proposta Pestalozziana de educação enaltecia a experiência como essencial para a construção do conhecimento desde a primeira infância.

Em toda sua obra Pestalozzi demonstra preocupação com a educação das crianças oriundas das classes populares. Ele tem uma visão de educação politizadora, entendendo-a como um instrumento de emancipação do ser humano e promotora da justiça e mobilidade 
social. Arce (2002) salienta que esta concepção educacional de Pestalozzi se deve ao fato dele ter vivido uma infância marcada pela pobreza e ter testemunhado as situações de injustiça e opressão que circundava seu povo. Contudo, a visão de educação de Pestalozzi também foi influenciada pela moral protestante que se faz presente em suas obras, a exemplo do romance Leonardo e Gertrudes, no qual a educação tem por finalidade a humanização do homem.

Gertrudes conversou da mesma maneira com todas suas crianças sobre suas falhas, até mesmo dizendo à pequena Peggy: "Você não deve ser tão impaciente por sua sopa, ou eu a farei esperar mais uma outra vez, e a darei para os outros". Quando isso terminou, as crianças dobraram suas mãos e fizeram suas orações da noite como de costume, seguidas por uma oração especial para o sábado à noite, que Gertrudes lhes avia ensinado. Quando a mãe pronunciou a benção final, todos se sentaram quietos [...] (ARCE, 2002, p. 108 - 109 apud PESTALOZZI, 1885).

Nota-se aí, a importante função desempenhada pela mulher e pelo Protestantismo na educação Pestalozziana. Neste caso, a mãe aconselha suas crianças uma a uma levandoas a refletirem sobre suas ações, cumprindo assim seu papel de educadora inata e de moral cristã inabalável. Este episódio também tem a função de ensinar as crianças a ser obedientes evitando sua degradação moral e doutrinando-as a reverenciar o Criador e a refletirem sobre suas vidas buscando sempre fazer a vontade do Pai do céu.

Pestalozzi via a aprendizagem do conteúdo como necessária, mas para ele não era tudo. O importante mesmo era a formação humana da criança, uma vez que esta conduziria à perfeição e deveria ser ofertada pela escola suprindo a carência familiar. $\mathrm{O}$ autor concebia a criança como um ser naturalmente bom, que não precisava de castigos físicos para ser educada, pois esses só piorariam a situação, bastaria apenas que a mãe a educasse com amor e firmeza.

Friedrich August Froebel (1782 - 1852) filósofo alemão que se tornou um grande educador e fundou o primeiro Kindergarten (jardim-de-infância). Para ele a educação é fundamentada na tríade Deus, natureza e humanidade, também conhecida como "Unidade Vital", conceito que inclui os processos de interiorização e exteriorização do conhecimento, responsáveis pela consolidação da educação. Segundo Arce (2002), o processo de interiorização acontece quando a criança recebe o conhecimento do mundo exterior e permite que ele toque o seu interior, assim o conhecimento parte do simples para o mais complexo. No processo de exteriorização a criança exterioriza o interior ao trabalhar com as coisas concretas e toma consciência de seu ser. Neste momento, a educação acontece.

Toda a teoria froebeliana é permeada pelo princípio divino, segundo o qual, Deus é a origem de todas as coisas. Ao observar a natureza e o desenvolvimento da criança, Froebel entendeu que ambos possuem leis próprias, identificando entre elas uma grande semelhança, por isso, ele acreditava na natureza como elo entre Deus e a humanidade. Partindo desse princípio, Froebel acreditava que a educação em sua organização curricular deveria seguir as leis da natureza, logo sua concepção de educação está intimamente conectada à religião protestante, ao respeito à natureza e à espontaneidade da criança, contrapondo-se à ideia de educação infantil com a finalidade de obter conhecimentos e de preparação para o futuro.

Na pedagogia froebeliana, a educação infantil não visa a aquisição de conhecimento, mas à promoção do desenvolvimento. A educação é vista 
como parte do processo geral de evolução pela qual todos os indivíduos estão unidos à natureza e fazem parte do mesmo processo. [...] A vida em que a criança deve ser inserida não é a vida do adulto, mas a vida que a rodeia no presente. A educação ocorre no processo, não no passado ou no futuro (KISHIMOTO e PINAZZA, 2007, p. 46).

Neste sentido, é possível compreender por que Froebel tornou-se uma referência no campo da educação da infância, dentro e fora da Europa, pois suas ideias acerca da infância revelaram uma criança que embora seja vista como a inocente, é também detentora de uma força interior que impulsiona seu desenvolvimento. Assim, conforme Kishimoto e Pinazza (2007) o conceito de infância deixa de ser o da época renegada, na qual a criança era vista como miniatura dos adultos e torna-se um ser a desabrochar. Froebel se refere às salas de educação infantil como "jardins-de-infância" no qual a criança é uma sementinha que precisa ser regada pela professora, a quem ele denomina de jardineira, inaugurando uma visão romântica de educação infantil, fundamentada nas leis da natureza e no desenvolvimento espontâneo da criança.

Uma das maiores contribuições de Froebel para a educação infantil foi a introdução do brinquedo como atividade nas escolas. Segundo Arce (2002), para Froebel a brincadeira é coisa séria e essencial ao desenvolvimento humano da criança. A criança que tem liberdade para brincar espontaneamente até ser vencida pelo cansaço físico será um adulto determinado e bem resolvido, capaz de sacrificar-se por si próprio e pelo bem dos outros. Por isso, ele criou brinquedos "chamados por ele de dons" de diferentes modelos, formas e cores que estimulam a curiosidade infantil e auxiliam no desenvolvimento da criança e na elaboração de conceitos matemáticos.

Na sua obra Pedagogia dos jardins-de-infância, Froebel (1917) apresenta os seus brinquedos, criados para auxiliar a brincadeira infantil sem ferir seu desenvolvimento natural. Os brinquedos criados para este fim foram chamados de "dons". Froebel assim chamou esses brinquedos, ou materiais educativos [...] Quando colocou seu foco educacional sobre os "dons" como forma de desenvolver a criança brincando, ele o fez porque achava que a única forma de a criança desenvolver sua inteligência e sua essência humana (que para Froebel era o mesmo que essência divina) seria através de sua ação e para isso ela necessitaria de materiais que a impulsionassem a agir (ARCE, 2002, p.193-194).

Froebel e Pestalozzi tinham os seguintes conceitos em comum a respeito da Educação: esta deveria ser desempenhada pela mãe, ter como base principal a religião protestante e a valorização da natureza. Além disso, ambos consideravam a brincadeira como um importante instrumento para a formação da criança em seus aspectos cognitivos e afetivos. Todavia, eles também divergiam em suas concepções educacionais, por exemplo, em toda a obra de Pestalozzi a preocupação com a população pobre se faz presente, o que não acontece no trabalho de Froebel, que se dedica mais às questões de ordem espiritual do que material, sendo este o motivo do desentendimento pedagógico entre eles, pois Froebel acusava Pestalozzi de reduzir o homem às preocupações sociais relacionadas à vida terrena, esquecendo-se de sua natureza espiritual e eterna.

Tanto Froebel, quanto Pestalozzi viveram em um contexto histórico dominado pela ideologia burguesa capitalista que reduzia a mulher e a criança à vida doméstica e religiosa excluindo-as completamente da vida pública. As características dessa ideologia encontravam-se presentes no pensamento de tais autores e influenciaram a formulação de 
suas teorias educacionais de modo que, embora houvesse algumas discordâncias entre suas pedagogias, a semelhança entre elas superava as divergências. Assim o pensamento pedagógico de ambos e as experiências vividas nas escolas fundadas por eles, principalmente os Kindergarten (jardins-de-infância) alemães, espalharam-se com o apoio de seus discípulos e colaboradores por toda a Europa e ultrapassaram as fronteiras do continente europeu, chegando aos Estados Unidos e outros países, inclusive ao Brasil.

Deste modo, Rousseau, Pestalozzi e Froebel foram responsáveis pelo desenvolvimento de uma nova concepção de infância na Europa. Eles foram e continuam sendo considerados autoridades no que se refere à Educação Infantil. Embora outros importantes educadores e educadoras tenham surgido ao longo da História da Educação Infantil, alguns fundamentados nestes precursores, outros discordando deles, os três continuarão sendo reconhecidos pelo pioneirismo, que numa época anterior à Psicologia os impulsionou a investigar o comportamento da criança e realizar importantes descobertas acerca de como ela se desenvolve em seus aspectos psicológicos, afetivos e cognitivos.

\section{Os percursos da Infância Brasileira na luta pela conquista do Direito à Educação Infantil}

Desde a chegada dos portugueses ao Brasil que a infância tem sido tratada de maneira negligente, pois as crianças que viajavam para a colônia a bordo dos navios lusitanos eram separadas e tratadas de acordo com a classe socioeconômica de suas famílias. As crianças descendentes de famílias urbanas com maior poder aquisitivo, chamadas de pajens, usufruíam de certa proteção durante a viagem, a elas era proposto as melhores condições de trabalho. Mas a maioria das crianças eram vítimas de toda espécie de maus-tratos como: trabalhos forçados, agressão física, fome, assédio sexual e estupros.

Nos naufrágios, essas eram as que mais sofriam. Não tinha prioridade de embarque nos momentos de fuga, nem tão pouco espaço disponível nas embarcações de menor porte. [...] As crianças que sobreviviam a todas essas situações ainda corriam o risco de ataque dos piratas e corsários, sendo escravizadas ou vendidas (LOPES, 2005, p. 16).

Em 1549, com a chegada dos primeiros jesuítas, chefiados pelo padre Manoel da Nóbrega, e o inicio do processo de colonização do Brasil, surge o primeiro sistema educacional brasileiro. A pedagogia jesuítica era fundamentada no cristianismo e regida pelo Ratio Studiorum (conjunto de regras e métodos educacionais que regia as práticas pedagógicas dos jesuítas). A finalidade primordial dos padres jesuítas, nome dado aos membros da Ordem religiosa denominada Companhia de Jesus, fundada em 1534 por Inácio de Loyola, era combater a expansão do protestantismo e divulgar o Catolicismo.

A educação jesuítica possuía um caráter dual, na medida em que aos curumins era proporcionada apenas uma mera instrução impregnada da cultura portuguesa, enquanto que aos filhos dos colonizadores se oferecia a verdadeira educação. A estes era ensinado a ler, escrever, contar, eles cursavam Letras, Ciências, Filosofia e aqueles que desejavam seguir a carreira eclesiástica estudavam Teologia, esse jovens completavam sua formação na Universidade de Coimbra em Portugal. Neste contexto, as mulheres e os negros eram completamente excluídos. Evidencia-se aí, o descaso da educação jesuítica para com a infância, em especial a infância social e economicamente desfavorecida. A ela foi imposto um processo de aculturação (no caso dos indígenas) e de exclusão (no caso dos negros). 
$\mathrm{Na}$ sociedade colonial brasileira patriarcalista e escravocrata não havia espaço privilegiado para as crianças. Elas não eram tratadas de maneira afetuosa, pode-se afirmar que não havia no Brasil nascente um sentimento especial de afeto, cuidado e proteção para com a infância. Em se tratando da criança escrava, Farias (2005) salienta que a situação era bem pior, a esta o direito à infância era totalmente usurpado, uma vez que lhes era retirado até o direito à amamentação, pois assim que os filhos das senhoras brancas nasciam eram entregues aos cuidados da ama-de-leite que deveria amamentá-los e criá-los.

A primeira instituição de caridade criada para prestar atendimento à infância desamparada foi a Casa ou Roda dos Expostos em 1726 na Bahia, posteriormente outras casas foram criadas no Rio de Janeiro e em outras províncias. Esta instituição acolhia indiscriminadamente crianças brancas, mestiças e principalmente negras, pois as mães escravas viam na roda a esperança de salvar seus filhos do trágico destino da escravidão. Segundo Marcílio (2003), a Roda dos Expostos foi inspirada no modelo medieval europeu e recebeu esse nome devido ao seu funcionamento: no muro da instituição tinha um dispositivo giratório de madeira onde os bebês enjeitados eram colocados. Em seguida, a pessoa girava a roda e o bebê já estava do lado de dentro da Santa Casa de Misericórdia, na sequência uma cordinha era puxada e uma sineta tocava para avisar que mais uma criança havia sido abandonada. Esse sistema tinha como finalidade manter o anonimato de quem abandonou a criança.

Apesar da Roda dos Expostos ter marcado a história da infância rejeitada no Brasil durante séculos, desde a época Colonial até meados do século XIX, ela acabou fracassando em seus objetivos, uma vez que não existiam condições dignas de higiene em seus alojamentos, nem qualidade no atendimento das crianças, pois o acolhimento das mesmas era feito nas Santas Casas de Misericórdia junto aos doentes. Isto explica o alto índice de mortalidade infantil, um grande número de crianças abandonadas nessas instituições não chegava à idade adulta.

Embora esta instituição de caridade tenha desenvolvido um importante papel social no combate ao abandono das crianças, ao infanticídio e ao alto índice de mortalidade infantil, ela também possuía um lado sombrio, caracterizado pela exploração da infância, já que as crianças ao completarem a idade de saírem da Roda dos Expostos eram enviadas para o trabalho forçado. Nota-se então, que essa primeira forma de "auxílio institucionalizada" à infância brasileira não possuía intenção pedagógica, pois não havia alusão à educação. Além disso, incentivava a prática ilegal da exploração do trabalho infantil.

Com a chegada de D. João VI e a família real ao Brasil em 1808, Aranha (1996) salienta que o país passou por uma série de modificações nos diversos campos tais como: na economia; a abertura dos portos para comercializar com países amigos e a criação do Banco do Brasil; na cultura; criação de museus, de biblioteca, da imprensa régia, a vinda de artistas europeus para retratarem as belezas naturais e a criação do Jardim Botânico; na educação; recebeu um novo impulso com a criação da Escola Politécnica e os seguintes cursos superiores - Medicina, Direito e Engenharia.

Contudo, esse desenvolvimento não contemplava a grande maioria da população composta por trabalhadores rurais e escravos que continuava excluída do progresso científico e cultural da época, principalmente no que tange à educação. Nesta perspectiva, educação de qualidade estava designada à elite branca que contratava preceptores para alfabetizar suas crianças menores de sete anos em casa, pois não havia o compromisso com a educação dessas crianças, era grande o descaso para com a educação da infância, principalmente a infância pobre e moralmente abandonada. 
Enquanto na Europa em 1840, segundo Arce (2002), Froebel fundou seu primeiro Kindergarten (jardim-de-infância) destinado às crianças menores de seis anos, e a partir daí, outros jardins-de-infância foram sendo criados na Alemanha e por toda a Europa entre os anos de 1843 e 1844, no Brasil ainda não havia instituições escolares para atender às crianças menores de sete anos. De acordo com Bastos (2001) o primeiro jardim-de-infância brasileiro foi fundado no Rio de Janeiro em 1875, pelo médico Joaquim José Menezes Vieira e sua esposa D. Carlota. Inspirado na teoria de educação froebeliana, esta instituição de educação infantil era privada e estava direcionada às crianças da elite, nela era ensinado leitura, escrita, ginástica, música, matemática, religião, dentre outras atividades. Contudo, só as crianças do sexo masculino de três a seis anos podiam frequentar os jardins-deinfância no Brasil.

Neste momento, entre o fim do século XIX e início do século XX, o Brasil passava por um período de transição política, do Império para a República, marcado por grandes transformações de ordem econômica e social que repercutiram em todos os âmbitos da vida social, em especial no campo da educação. De acordo com Ghiraldelli (2008) e Aranha (1996), as modernizações ocorridas no fim do século XIX, como o fim da escravidão (1888), a proclamação da República (1889) e o rápido crescimento urbanoindustrial provocaram mudanças significativas em todos os setores da sociedade brasileira. Tais mudanças ecoaram principalmente no setor educacional, pois o fortalecimento da burguesia industrial exigia mão-de-obra qualificada, o que não havia no Brasil, uma vez que a educação da época era totalmente aristocrática atendendo apenas a uma minoria social, enquanto uma grande parcela da sociedade era totalmente excluída da escola ou recebia uma mera instrução rudimentar.

A partir daí, a educação tornou-se tema de discussões frequente no cenário político nacional e teve ilustres defensores, a exemplo do intelectual Rui Barbosa, que lutava para que a educação pública, gratuita e laica tornasse um direito de todo cidadão brasileiro desde a infância até a universidade. De acordo com Kuhlmann Jr. (2011) embora o jardim de infância tenha chegado ao Brasil como instituição elitizada e privada, desde 1882, que Rui Barbosa já defendia sua implantação no Brasil, para ele o país só se desenvolveria quando a educação estivesse entre as principais prioridades do governo. Todavia, a proposta de Rui Barbosa não obteve o êxito almejado por ele, e durante todo o período do Império e da Primeira República a educação infantil continuou sendo abandonada pelos governantes brasileiros, que muito pouco ou nada fez em prol dela.

No Brasil, devido ao alto índice de mortalidade infantil, quem primeiro preocupouse com as crianças pequenas foram os médicos higienistas que usavam as creches como laboratórios médicos, onde as crianças pobres eram tratadas. No caso da influência jurídico-policial, havia uma segregação da infância pobre e moralmente abandonada que era considerada uma ameaça para a elite, por isso era necessário construir creches e jardins de infância para manter essas crianças longe da criminalidade, afirma Kuhlmann Jr. (2011). No que tange à influência religiosa, era histórico o trabalho caridoso desenvolvido pela Igreja Católica em prol das crianças órfãs, pobres e abandonadas.

Segundo Kramer (2011) só em 1908 foi criada a primeira creche popular no Brasil, enquanto na França as creches surgiram na primeira metade do século XIX. "A implantação de creches na França é atribuída a Marbeau, nascendo a primeira em 14 de novembro de1844" (PARDAL, 2005, p. 60). Diferente das creches francesas que surgiram para atender às crianças cujas mães trabalhavam na indústria, as creches brasileiras surgiram para auxiliar as crianças oriundas das camadas populares cujas mães trabalhavam como domésticas. 
Em 1899, foi fundado no Rio de Janeiro, o Instituto de Proteção e Assistência à Infância, pelo médico higienista Arthur Moncorvo Filho. Esta instituição teve papel fundamental no combate à mortalidade infantil através do atendimento às crianças menores de oito anos, da educação das gestantes e mães acerca dos cuidados que deveriam ter com os recém-nascidos e do velar pelas crianças trabalhadoras ou criminosas, conforme Kramer (2011). Esta instituição multiplicou-se rapidamente pelo país, em 1929 já existia 22 filiais, sendo 11 delas com creches.

Segundo Kuhlmann Jr. (2011) este período foi marcado pela abertura de instituições sociais de proteção à infância em várias partes do Brasil, e pela realização de muitos congressos internacionais que apresentavam os jardins de infância, as creches e salas de asilo francesas como experiências de educação infantil. Em 1922, no Rio de Janeiro, foi realizado o Primeiro Congresso Brasileiro de Proteção à Infância, cuja finalidade era refletir sobre os diversos problemas de ordem social, pedagógica, médica e higiênica que afetavam a sociedade, a mulher grávida e, sobretudo, às crianças brasileiras.

A partir de 1929 o mundo foi afetado por uma grave crise econômica que repercutiu diretamente no poder da elite brasileira afetando o domínio político da oligarquia cafeicultora e dificultando sua permanência no controle da política nacional. Outro episódio que ameaçava a política café-com-leite era o crescimento dos grupos opositores que estavam dispostos a lutar para derrubar a República Velha. Neste contexto, o clima no país era de insatisfação de vários setores da sociedade civil e tensão política, culminando com a eclosão da Revolução de 1930 que depôs o governo de Washington Luís. Com esta Revolução, Getúlio Vargas chegou ao poder e realizou muitas mudanças de ordem político-econômica e sociocultural que provocaram grandes modificações na História do Brasil e da Educação Brasileira.

Iniciava-se aí, o período da História brasileira conhecido como a Era Vargas que foi dividido, segundo FAUSTO (2007) em três fases: Governo Provisório (1930-1934); Governo Constitucional (1934-1937) e Estado Novo (1937-1945). Getúlio Vargas deparou com um Brasil economicamente agroexportador, pouco industrializado, repleto de desigualdades sociais e regionais, com índices alarmantes de desemprego e analfabetismo da maioria de sua população. Logo, coube a Vargas a tarefa de elaborar e implantar políticas econômicas e sociais que tivesse por finalidade libertar o país da crise na qual se encontrava submerso.

Segundo Ghiraldelli (2008), no campo da educação a primeira atitude do governo Vargas ao assumir a presidência em 1930, foi criar o Ministério da Educação e Saúde Pública, cujo cargo de ministro fora ocupado por Francisco Campos que realizou a reforma educacional que recebeu seu nome. Tal reforma desempenhou relevante papel na organização nacional do ensino, estruturação das Universidades e criação do Conselho Nacional de Educação.

Durante os 15 anos do governo Vargas muitas reformas educacionais foram perpetradas e em 1932 foi publicado o texto denominado "Manifesto dos Pioneiros da Educação Nova", elaborado por um grupo de intelectuais, cujos principais representantes eram: Fernando de Azevedo, Anísio Teixeira e Florestan Fernandes. Este documento declarava que a Educação deveria ser prioridade do governo, pois só ela seria capaz de promover o desenvolvimento econômico e cultural fundamentais para impulsionar o crescimento do país. Neste sentido, o Manifesto estabelecia como princípio básico para a educação pública brasileira a "laicidade, a gratuidade, a obrigatoriedade [...]" (GHIRALDELLI, 2008, p. 45).

Contudo, no que tange à Educação infantil, as reformas empreendidas pelo governo Vargas não a menciona, transparecendo assim, o descaso do Estado para com a educação 
da infância. Este fato evidencia a inexistência de políticas públicas de educação direcionadas para as crianças menores de sete anos. Kramer (2011) salienta que devido à situação de miserabilidade em que vivia a maioria das crianças e suas famílias, vítimas de doenças, desnutrição, abandono e delinquência, o Estado nacional Varguista reconhece a necessidade de intervir socialmente junto à infância desamparada. Porém, solicita a colaboração da sociedade civil argumentando a ausência de recursos para garantir à infância o direito à cidadania, atitude esta que reforça o histórico caráter filantrópico e assistencialista que tem marcado o atendimento da infância Brasileira.

Em decorrência do projeto desenvolvimentista implantado no país pelo governo Vargas, a infância tornou-se reconhecida como o futuro do Brasil. Por isso, conquistou importância diante do Estado que passou a preocupar-se em "protegê-la e educá-la", não para emancipá-la, mas para a subserviência e o trabalho, de acordo com os princípios autoritários impostos pelo governo. A partir de então, vários órgãos públicos e privados foram criados para atender à criança e ao adolescente tais como:

Em 1940, Departamento Nacional da Criança, vinculado ao Ministério da Educação e Saúde Pública [...] Em 1941, Serviço de Assistência a Menores (SAM), vinculado ao Ministério da Justiça e Negócios Interiores [...] Em 1942, Legião Brasileira de Assistência (LBA) que visava assistir às mães e crianças na primeira infância [...] Em 1946, Serviço Nacional do Aprendizado Industrial (SENAI), com o objetivo de formar jovens com qualificações industriais, (NUNES, 2005, p. 76).

Todos estes programas, dentre outros estavam mais direcionados à área de saúde, higiene, trabalho, assistência social e jurídica do que a área de educação, alguns deles possuíam caráter de reclusão e criminalização. Percebe-se, que o Estado nacional Varguista, ao contrário do que se esperava, inaugurou uma visão da criança como trabalhadora e colaboradora com o progresso da pátria, ao invés de uma criança cidadã detentora de direitos.

Esta realidade ainda perdurou por algumas décadas sem que houvesse mudanças significativas, o que só começou a acontecer a partir de meados da década de 70 e 80 , período marcado pelas lutas da sociedade civil organizada pelo fim da ditadura militar em prol da redemocratização política do Brasil. Dentre as reivindicações populares, encontrava-se a exigência por melhorias na educação pública, de modo especial pela ampliação do número de vagas na educação infantil através da construção e manutenção de creches pelo poder público, pois devido à crescente urbanização e industrialização do país, um grande número de mulheres das camadas populares havia ingressado no mercado de trabalho. Neste contexto, nasceu um novo olhar sobre as crianças de zero a seis anos, uma vez que com a promulgação da Constituição Federal de 1988, a Educação Infantil passou a ser reconhecida como direito dessas crianças. Dessa forma, a criança menor de sete anos deixa de ser objeto de benevolência e passa ser cidadã de Direito.

Entretanto, o direito conquistado na Constituição de 1988, só se efetivou de fato com a promulgação da Lei Nº 9.394/96 - Lei de Diretrizes e Bases da Educação Nacional que integrou a Educação Infantil à Educação Básica em seu Art. 29 ao determina que:

A educação infantil, primeira etapa da educação básica, tem como finalidade o desenvolvimento integral da criança até seis anos de idade, em seus aspectos físicos, psicológicos, intelectual e social, complementando a ação da família e da comunidade (BRASIL, 1996). 
A partir daí, a Educação Infantil tornou-se a primeira etapa da Educação Básica. Logo, passou a está vinculada a secretaria de educação e não mais à assistência social, o que significa dizer que a educação da infância ascendeu, conquistou e vem conquistando um lugar especial nos debates políticos, científicos, entre pesquisadores do meio acadêmico, dentre outros setores da sociedade civil organizada. Nesta perspectiva, as creches e pré-escolas inauguraram uma nova era em sua história, na qual cuidar e educar tornaram-se parceiras na educação integral das crianças de zero a cinco/seis anos.

De lá para cá, as discussões sobre a Educação Infantil tem ocupado cada vez mais espaço no panorama político educacional brasileiro. Leis, documentos, diretrizes, referenciais e políticas nacionais de educação direcionadas às crianças de zero a cinco/seis anos foram e estão sendo elaboradas com a finalidade de assegurar à primeira infância o direito à Educação Infantil pública, gratuita e de qualidade. No entanto, como afirma Campos (2008), há no Brasil um histórico divórcio entre a legislação e a realidade, ou seja, entre o que se diz e o que se faz há um abismo, por isso, após mais de duas décadas da promulgação da Constituição de 1988 e mais de dez anos de promulgação da nova LDB 9394/96, ainda existem muitos obstáculos a ser enfrentados no campo da Educação Infantil.

Neste sentido, Haddad (2008) aponta alguns desafios tradicionais que precisam ser superados como: a histórica dicotomia entre cuidar e educar; a alternância entre assistência e escolarização; a dissensão entre a família da criança e a instituição que presta atendimento. Além dessas barreiras, existem outras, a exemplo da carência existente na formação dos professores que atuam na educação infantil, bem como dos demais profissionais que agem junto às crianças. Outro problema muito visível atualmente na educação infantil é escassez de creches, principalmente nas grandes cidades e capitais do país, onde a demanda por vagas é alta devido à presença cada vez maior da mulher no mercado de trabalho.

Percebe-se então, que apesar dos avanços registrados nas últimas décadas da luta empreendida por familiares, sociedade civil, professores, cientistas da educação e políticos em defesa do direito das crianças à Educação Infantil de qualidade, ainda há muito por fazer para que de fato todos os Direitos conquistados legalmente se consolidem. Contudo, é preciso dá continuidade à luta para que os Direitos das crianças de zero a cinco anos a uma Educação Infantil comprometida com a promoção do desenvolvimento infantil em todos os seus aspectos, biopsicossociais, afetivos, cognitivos e culturais sejam de fato concretizados.

\section{Considerações Finais:}

No decorrer da realização desse estudo foi possível perceber o quanto a infância tem sido socialmente excluída. Durante séculos ela foi relegada a último plano e vítima de toda espécie de violência praticada por uma sociedade predominantemente adultocêntrica. Outro aspecto importante revelado neste trabalho foi o modo como as concepções de infância foram modificando-se de acordo com as transformações sócio-políticas, econômicas e culturais pelas quais passou a Europa.

As transformações ocorridas no continente europeu duraram séculos. Elas tiveram início a partir do nascimento, consolidação da Modernidade e ascensão da burguesia capitalista cooperando para a inauguração de uma nova concepção de infância na Europa. Considerando que o Brasil foi colonizado por europeus torna-se evidente a influência portuguesa na formação da sociedade brasileira. Nesse contexto, a Educação Brasileira em todos os seus níveis tem sido influenciada pelos conceitos e valores advindos de Portugal. 
No que tange à Educação Infantil, a presença lusitana foi determinante no Brasil desde a fundação das primeiras instituições de caráter caridoso, filantrópico e assistencialista. Este atendimento era caracterizado apenas pelo cuidado com as crianças pequenas em substituição à mãe, totalmente desvinculado de qualquer intenção pedagógica.

Por isso, durante séculos a infância brasileira oriunda das camadas populares não teve acesso à educação infantil. E, ainda hoje, após a promulgação de leis importantes na defesa do direito das crianças pequenas à Educação Infantil, existem muitas crianças sem usufruir desse direito por diversos motivos, dentre eles destaca-se a ausência de vagas para atender a todas as crianças.

Sendo assim, é inadmissível que em pleno século XXI, após tantas lutas empreendidas em prol dos direitos da infância em diversas partes do mundo e das conquistas alcançadas neste campo, ainda se presencie situações de massacres de crianças que são vítimas de diversas formas de violências e maus-tratos tanto na família, como na rua ou até mesmo nas instituições que deveriam cuidar e educar essas crianças. Diante disso, faz-se necessário que a sociedade civil organizada reivindique junto ao poder público o cumprimento das leis, documentos e políticas públicas que asseguram os direitos da criança garantidos pela Constituição Federal de 1988, pelo Estatuto da Criança e do Adolescente de 1990 e o direito à Educação Infantil assegurado pela nova LDB 9394/96.

\section{Referências}

ARANHA, Maria Lúcia de Arruda. História da educação. São Paulo: Moderna, 1996.

ARCE, Alessandra. A Pedagogia na "era das revoluções": uma análise do pensamento de Pestalozzi e Froebel. Campinas: Autores Associados, 2002.

ARIÈS, Philippe. História social da criança e da família. Traduzido por Dora. Flaksman. Rio de Janeiro: LTC, 1981.

BASTOS, Maria Helena Camara. Jardim de Crianças: o pioneirismo do Dr. Menezes Vieira (1875-1887). In: MONARCHA, Carlos (Org.). Educação da infância brasileira (1875-1983). São Paulo: Autores Associados, 2001, p. 31-80.

BRASIL. Lei de Diretrizes e Bases da Educação Nacional. Lei $n^{\circ}$ 9.394, de 20 de dezembro de 1996.

CAMPOS, Maria Malta. A legislação, as políticas nacionais de educação infantil e a realidade: desencontros e desafios. In: MACHADO, Maria Lúcia de A. (Org.). Encontros e desencontros em educação infantil. 3.ed. São Paulo: Cortez, 2008, p. 27-33.

FARIAS, Mabel. Infância e educação no Brasil nascente. In: VASCONCELLOS, Vera Maria Ramos de (Org.). Educação da infância: história e política. Rio de Janeiro: DP\&A, 2005, p. 33-48.

FAUSTO, Boris. História do Brasil.12 ed. 2. reimp. São Paulo: USP, 2007.

GHIRALDELLI, Júnior Paulo. História da Educação Brasileira. São Paulo: 3 ed. Cortez, 2008.

HADDAD, Lenira. Substituir ou Compartilhar? O papel das instituições de educação infantil no contexto da sociedade contemporânea. In: MACHADO, Maria Lúcia de A. (Org.). Encontros e desencontros em educação infantil. 3.ed. São Paulo: Cortez, 2008, p. 91-102. 
KISHIMOTO, Tizuko Morchida e PINAZZA, Mônica Appezzato. Froebel: uma pedagogia do brincar para infância. In: Pedagogia (s) da Infância: dialogando com o passado: construindo o futuro. FORMOSINHO, O. Júlia; Tizuko Morchida e PINAZZA, Mônica Appezzato. (Orgs). Porto Alegre: Artmed, 2007, p. 37-60.

KRAMER, Sônia. Infância, cultura contemporânea e educação contra a barbárie. In: BAZÍLIO, Luiz Cavalieri e KRAMER, Sônia. Infância, Educação e Direitos Humanos. São Paulo: Cortez, 2008, p. 83-106.

Cortez, 2011.

A Política do Pré-Escolar no Brasil: a arte do disfarce. São Paulo:

KOHAN, Walter Omar. Infância. Entre educação e filosofia. Belo Horizonte: Autêntica, 2006.

KUHLMANN JÚNIOR, Moysés. Infância e educação infantil: uma abordagem histórica. Porto Alegre: Mediação, 2010.

LOPES, Jader Janer Moreira. Grumetes, pajens, órfãs do rei e outras crianças migrantes. In: VASCONCELLOS, Vera Maria Ramos de (Org.). Educação da infância: história e política. Rio de Janeiro: DP\&A, 2005, 13-30.

MARCÍLIO, Maria Luísa. A roda dos expostos e a criança abandonada na história do Brasil 1726-1950. In: FREITAS, Marcos Cezar de. (Org). História social da infância no Brasil. São Paulo: Ed. Cortez, 2003, p. 53-79.

NUNES, Deise Gonçalves. Reconhecimento social da infância no Brasil: da menoridade à cidadania. In: VASCONCELLOS, Vera Maria Ramos de (Org.). Educação da infância: história e política. Rio de Janeiro: DP\&A, 2005, p. 73-96.

PARDAL, Maria Vitória de Carvalho. O cuidado às crianças pequenas no Brasil escravista. In: VASCONCELLOS, Vera Maria Ramos de (Org.). Educação da infância: história e política. Rio de Janeiro: DP\&A, 2005, p. 51-70.

POSTMAN, Neil. O desaparecimento da infância. Rio de Janeiro: Graphia Editorial, 1999.

ROUSSEAU, Jean-Jacques. Emílio, ou Da educação. Tradução de Elia Ferreira Edel. 3 ed. Rio de Janeiro: Bertrand Brasil, 1995.

RUA, Maria Adelaide. Infância em territórios de pobreza: os falares e sentires das crianças. In: VASCONCELOS, Vera Maria R.; SARMENTO, Manuel Jacinto (Org.). Infância (in)visível. Araraquara: J\&M Martins, 2007.

SARMENTO, Manuel Jacinto. Visibilidade social e estudo da infância. In: VASCONCELOS, Vera Maria R.; SARMENTO, Manuel Jacinto (Org.). Infância (in)visível. Araraquara: J\&M Martins, 2007, p. 25-46.

Infância, Exclusão Social e Educação como Utopia Realizável. Educação \& Sociedade, ano XXII, no 78, Abril/2002, p. 265-282.

SOUZA, Edmacy Quirina. Por uma compreensão Histórico-Filosófica da Infância. In: CAMPOS, Gleisy Vieira. LIMA, Lílian (Orgs). Por dentro da educação infantil: a criança em foco. RJ: Wak Ed. 2010, p. 15-28.

Recebido: abril-13 Aprovado: setembro-13 